\title{
Bacterial Cellulose-Derived Three-Dimensional Carbon Current Collectors for Dendrite-Free Lithium Metal Anodes
}

\author{
Yunbo Zhang ${ }^{1}$, Qiaowei Lin ${ }^{2}$, Junwei Han ${ }^{2}$, Zhiyuan Han ${ }^{2}$, Tong Li ${ }^{2}$, Feiyu Kang ${ }^{1,2}$, \\ Quan-Hong Yang ${ }^{3}$, Wei Lü ${ }^{2, *}$ \\ ${ }^{1}$ Tsinghua-Berkeley Shenzhen Institute (TBSI), Tsinghua University, Shenzhen 518055, Guangdong Province, China. \\ ${ }^{2}$ Shenzhen Geim Graphene Center, Tsinghua Shenzhen International Graduate School, Tsinghua University, Shenzhen 518055, \\ Guangdong Province, China. \\ ${ }^{3}$ State Key Laboratory of Chemical Engineering, School of Chemical Engineering and Technology, Tianjin University, Tianjin \\ 300072, China.
}

\begin{abstract}
Lithium (Li) metal anodes are critical components for next-generation high-energy density batteries, owing to their high theoretical specific capacity ( 3800 $\left.\mathrm{mAh} \cdot \mathrm{g}^{-1}\right)$ and low voltage $(-3.040 \mathrm{~V}$ versus the standard hydrogen electrode). However, their applications are hindered by dendrite growth, which potentially induces inner short circuit and leads to safety issues. Employing three-dimensional (3D) current collectors is an effective strategy to suppress dendrite growth by decreasing the local current density. However, many of the reported 3D current collectors have a lithiophobic surface, which leads to non-uniform $\mathrm{Li}^{+}$ion deposition. Thus, a complicated modification process is required to increase the lithiophilic property of the current collectors. In addition, they have a large weight or volume, which greatly lowers the energy density of the entire anode. In this work, we report a

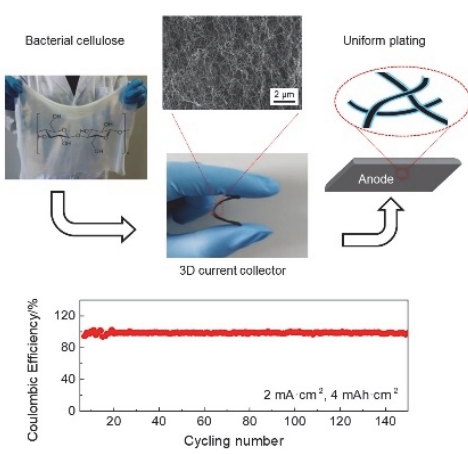
lightweight 3D carbon current collector with a lithiophilic surface by employing the direct carbonization of low-cost bacterial cellulose (BC) biomass. The current collector is composed of electrically conductive, robust, and interconnected carbon nanofiber networks, which provide sufficient void space to accommodate a large amount of Li and buffer the volume changes during Li plating and stripping. More importantly, homogeneously distributed oxygen-containing functional groups on the nanofiber surface are retained by controlling the carbonization temperature. These functional groups serve as uniform nucleation sites and help realize uniform and dendrite-free Li deposition. Notably, the areal mass density of the $3 \mathrm{D}$ carbon current collector was only $0.32 \mathrm{mg} \cdot \mathrm{cm}^{-2}$ and its mass ratio in the whole anode was $28.8 \%$, with a capacity of 3 $\mathrm{mAh} \cdot \mathrm{cm}^{-2}$. This $3 \mathrm{D}$ carbon current collector facilitates the stable working of the half cells for 150 cycles under a high current density of $3 \mathrm{~mA} \cdot \mathrm{cm}^{-2}$ or a high capacity of $4 \mathrm{mAh} \cdot \mathrm{cm}^{-2}$. Symmetric cells exhibit a steady cycling life as long as $600 \mathrm{~h}$ under a current density of $1 \mathrm{~mA} \cdot \mathrm{cm}^{-2}$ and a capacity of $1 \mathrm{mAh} \cdot \mathrm{cm}^{-2}$. Moreover, appreciable cycling performance was realized in the full cells when the anodes were paired with $\mathrm{LiNi}_{0.8} \mathrm{Co}_{0.15} \mathrm{Al}_{0.05}$ cathodes. Furthermore, the low-cost raw materials and the simple preparation method promise significant potential for the future applications of the proposed 3D current collectors.
\end{abstract}

Key Words: Lithium metal anode; Bacterial cellulose; Three-dimensional current collector; Lithium dendrite; Oxygen-containing functional group

\footnotetext{
Received: August 31, 2020; Revised: September 29, 2020; Accepted: September 30, 2020; Published online: October 19, 2020.

${ }^{*}$ Corresponding author. Email: lv.wei@sz.tsinghua.edu.cn; Tel.: +86-755-86964142.

The project was supported by the National Key Research and Development Program of China (2018YFE0124500), the National Natural Science Foundation of China (51972190), the Guangdong Natural Science Funds for Distinguished Young Scholars (2017B030306006), Shenzhen Basic Research Project (JCYJ20180508152037520).

国家重点研发计划(2018YFE0124500), 国家自然科学基金(51972190), 广东省杰出青年自然科学基金(2017B030306006)和深圳市科技计划基础研究 (学科布局)项目(JCYJ20180508152037520)资助
}

(C) Editorial office of Acta Physico-Chimica Sinica 


\title{
细菌纤维素衍生的三维碳集流体用于无枝晶的锂金属负极
}

\author{
张云博 ${ }^{1}$, 林乔伟 ${ }^{2}$, 韩俊伟 ${ }^{2}$, 韩志远 ${ }^{2}$, 李曈 ${ }^{2}$, 康飞宇 ${ }^{1,2}$, 杨全红 ${ }^{3}$, 吕伟 ${ }^{2,}{ }^{*}$ \\ 1 清华大学清华-伯克利深圳学院, 广东深圳 518055 \\ 2 清华大学深圳国际研究生院, 深圳盖姆石墨烯研究中心, 广东深圳 518055 \\ 3 天津大学化工学院, 化学工程联合国家重点实验室(天津大学), 天津 300072
}

\begin{abstract}
摘要: 锂金属是下一代高能量密度电池的关键负极, 然而其实用化面临着一系列问题, 主要包括循环过程中体积变化大、 枝晶生长等。使用三维集流体是解决这些问题的有效方法, 然而现有大多数三维集流体存在重量大、体积大、表面亲锂 性差、成本高等问题。针对上述问题, 本文以低成本的细菌纤维素为前驱体, 通过直接碳化制备出具有连通网络的轻质 三维碳集流体, 其表面均匀分布的含氧官能团可以促进锂离子的均匀成核和沉积, 有效抑制了枝晶生长。值得注意的是, 该 集流体的面密度仅为 $0.32 \mathrm{mg} \cdot \mathrm{cm}^{-2}$, 在 $3 \mathrm{mAh} \cdot \mathrm{cm}^{-2}$ 比容量的锂金属负极中质量占比仅为 $28.8 \%$ 。电化学测试结果表明, 该集 流体在 $3 \mathrm{~mA} \cdot \mathrm{cm}^{-2}$ 的高电流密度或 $4 \mathrm{mAh} \cdot \mathrm{cm}^{-2}$ 的高循环容量的工作条件下, 稳定循环超过 150 次, 并且在对称电池或与 $\mathrm{LiNi}_{0.8} \mathrm{Co}_{0.15} \mathrm{Al}_{0.05}$ 匹配的全电池中也表现出良好的电化学性能。
\end{abstract}

关键词: 锂金属负极; 细菌纤维素; 三维集流体; 锂枝晶; 含氧官能团 中图分类号: 0646

\section{Introduction}

Lithium (Li) metal is one of the most promising anodes for the next-generation Li batteries with high energy density due to its theoretically high capacity $\left(3800 \mathrm{mAh} \cdot \mathrm{g}^{-1}\right)$ and low voltage $(-3.040 \mathrm{~V}$ versus the standard hydrogen electrode). But the $\mathrm{Li}$ dendrite growth in the electroplating process hinders its practical use in rechargeable batteries as the dendrites can easily pierce through the separator, leading to the short circuit and the safety risks. Furthermore, the large volume fluctuations of $\mathrm{Li}$ metal during repeated plating/stripping processes will cause the structural degradation of the electrode and break the solid electrolyte interface (SEI), which significantly deteriorate the electrochemical performance of Li anodes ${ }^{1-4}$. Until now, many strategies have been proposed to control the electrochemical plating and stripping behaviors of Li metal, such as the use of electrolyte additives ${ }^{5-11}$ or high-concentration electrolyte ${ }^{12-14}$, protecting the Li metal surface by various coatings ${ }^{15-21}$ or using solid-state electrolytes ${ }^{22-25}$. Nevertheless, these strategies still cannot well block the dendrite growth or buffer the volume change under a practically high areal capacity and a long cyclic operation.

Using the three-dimensional (3D) current collector to suppress the Li dendrite growth has been shown as a simple but very effective strategy ${ }^{26-32}$. According to the Chazalviel's model, a lower local current density would lead to the fewer grown Li dendrites ${ }^{33}$. The $3 \mathrm{D}$ current collector with a high specific surface area effectively decreases the local current density and therefore suppresses the dendrite growth. Besides, the $3 \mathrm{D}$ structure also provides enough void space to accommodate the deposited Li metal during the plating and stripping processes, reducing the electrode swelling 27,29,31. However, the mostly-used 3D current collectors, such as the porous $\mathrm{Cu}$ or $\mathrm{Ni}$ and nanostructured carbons, generally have either a large weight or thickness, which reduces the specific capacity based on the whole electrode. Also, it is difficult for these current collectors to realize the uniform $\mathrm{Li}$ nucleation inside the 3D structure due to the lithiophobic framework or the lack of interaction sites with $\mathrm{Li}^{+}$ions ${ }^{31,34}$. Consequently, the $\mathrm{Li}$ metal tends to deposit on the top surface of the $3 \mathrm{D}$ current collector. A few strategies have been proposed to guide the deposition inside the $3 \mathrm{D}$ structure by tuning the surface chemistry of 3D framework using the lithiophilic coating or surface functionalization ${ }^{34,35}$, but the preparation and surface functionalization methods of these current collectors are always complicated, hindering their large-scale production and usage. Herein, we present a low-cost, lightweight and surface functionalized carbon current collector derived from bacterial cellulose (BC), which shows great potential for the real use in dendrite-free Li metal anodes.

\section{Experimental}

\subsection{Preparation of BC-derived 3D current collector}

Firstly, BC (Hainan Yide Food Co., Ltd.) was rinsed with DI water several times to remove the remained acid in the pellicles and then was treated with a freezing drying. The obtained BC aerogel was pyrolyzed under an argon atmosphere, where the heating procedure was elevating the furnace temperature at the rate of $5^{\circ} \mathrm{C} \cdot \mathrm{min}^{-1}$ to $180^{\circ} \mathrm{C}$ with $1 \mathrm{~h}$ staying, then elevating the furnace temperature at the rate of $5^{\circ} \mathrm{C} \cdot \mathrm{min}^{-1}$ to $230{ }^{\circ} \mathrm{C}$ with 1 $\mathrm{h}$ staying. For $\mathrm{BC}-500$, the following procedure was elevating the furnace temperature at the rate of $5{ }^{\circ} \mathrm{C} \cdot \mathrm{min}^{-1}$ to $500{ }^{\circ} \mathrm{C}$ with $1 \mathrm{~h}$ staying. For $\mathrm{BC}-800$, the procedure was elevating the furnace temperature at the rate of $5^{\circ} \mathrm{C} \cdot \mathrm{min}^{-1}$ to $520{ }^{\circ} \mathrm{C}$ with 1 $\mathrm{h}$ staying, then elevating the furnace temperature at the rate of 
$2{ }^{\circ} \mathrm{C} \cdot \mathrm{min}^{-1}$ to $800{ }^{\circ} \mathrm{C}$ with $1 \mathrm{~h}$ staying. For $\mathrm{BC}-1500$, the procedure was elevating the furnace temperature at the rate of $5{ }^{\circ} \mathrm{C} \cdot \mathrm{min}^{-1}$ to $520{ }^{\circ} \mathrm{C}$ with $1 \mathrm{~h}$ staying, then elevating the furnace temperature at the rate of $2{ }^{\circ} \mathrm{C} \cdot \mathrm{min}^{-1}$ to $1500{ }^{\circ} \mathrm{C}$ with 1 $\mathrm{h}$ staying. After the pyrolysis process, the $\mathrm{BC}$-derived $3 \mathrm{D}$ current collectors were obtained.

\subsection{Material Characterization}

Thermogravimetric analysis-differential scanning calorimetry (TGA-DSC) profile was recorded by METTLER TOLEDO DSC3 (Switzerland). FEI Tecnai (USA) and HITACHI SU8010 (Japan) were used to obtain the transmission electron microscope (TEM) and scanning electron microscope (SEM) images. Fourier transform infrared (FTIR) spectra were tested by Thermo Scientific Nicolet IS 50 (USA). X-ray diffraction (XRD) patterns were recorded by Bruker D8 Advance (Germany). Raman spectra were tested by Horiba LabRAM HR800 (Japan). Four-point meter was 4 Probes Tech RTS-9 (China). X-ray photoelectron spectroscope (XPS) was tested by ULVAC-PHI PHI5000 Versa Probe II (Japan).

\subsection{Electrochemical performance test in half cells}

To assess the electrochemical performance of the $\mathrm{BC}$-derived 3D current collectors, symmetric 2032 coin cells were assembled. Celgard 2400 (Celgard, LLC.) was used as the separator. $1 \mathrm{~mol} \cdot \mathrm{L}^{-1}$ Lithium bis(trifluoromethanesulphonyl) imide (LiTFSI) in 1,3-dioxolane (DOL) : 1,2-dimethoxyethane (DME) $(1: 1)$ with $2 \%$ lithium nitrate $\left(\mathrm{LiNO}_{3}\right)$ (Suzhou Dodo Chem Technology Co., Ltd.) was used as the electrolyte. The Li metal (Shenzhen Kejing Zhida Technology Co., Ltd.) was used as the counter electrode. All the galvanostatic measurements were conducted on a LAND multi-channel battery testing system (Wuhan LAND Electronic Co. Ltd., China). Before the Li plating/stripping processes, a slow charging/discharging procedure was applied to the cells at a current density of 0.05 $\mathrm{mA} \cdot \mathrm{cm}^{-2}$ in the voltage range of $0.01-1 \mathrm{~V}$. Electrochemical impedance spectroscopy (EIS) test of the cell was conducted with a VMP3 electrochemical workstation (BioLogic Sciences Instruments, France), where the frequency range was from 100 $\mathrm{kHz}$ to $100 \mathrm{mHz}$ for the EIS tests before cycling, and $100 \mathrm{kHz}$ to $10 \mathrm{mHz}$ for the EIS tests after cycling, respectively.

\subsection{Symmetric cell assessment}

The Li-containing electrode was prepared by the electrochemical plating method using BC-800 as the working electrode and $\mathrm{Li}$ metal as the counter electrode. The cells were assembled in the same way as the aforementioned half cells. 3 $\mathrm{mAh} \cdot \mathrm{cm}^{-2} \mathrm{Li}$ was plated into the $\mathrm{BC}-800$ at the rate of 0.1 $\mathrm{mA} \cdot \mathrm{cm}^{-2}$. After the plating, cells were disassembled and the BC-800 electrodes were washed with DME (Suzhou Dodo Chem Technology Co., Ltd.) for three times. After evaporation of the solvent, the Li-plated electrodes were finally obtained and denoted as 3D Li-BC. With the 3D Li-BC, symmetric cells were assembled and tested in the same way as the above half cells.

\section{5 $\mathrm{Li}-\mathrm{LiNi}_{0.8} \mathrm{Co}_{0.15} \mathrm{Al}_{0.05}$ (NCA) cell assessment}

3D Li-BC was used as the negative electrode, and the NCA (Shenzhen Kejing Zhida Technology Co., Ltd.) cathode was prepared by the slurry coating method. In the slurry, the mass ratio of NCA : SuperP (Guangdong Canrd New Energy Technology Co., Ltd.) : Poly(vinylidene fluoride) (PVDF) (Guangdong Canrd New Energy Technology Co., Ltd.) was 8 : $1: 1$. The slurry was coated on aluminum foil and the solvent was evaporated in vacuum at $120^{\circ} \mathrm{C}$. The cycling performance was tested in the voltage range of $2.8-4.3 \mathrm{~V}$, and the specific capacity was calculated based on the mass of NCA in the electrode.

\section{Results and discussion}

$\mathrm{BC}$ is a cheap and abundant bio-resource with a 3D interconnected nanoscale network (Fig. 1a and Fig. S1, Supporting Information), and can be carbonized to obtain an electrically conductive carbon framework. According to the TGA-DSC profile in Fig. S2, the mass loss of BC mainly occurs under the temperature ranging from 280 to $380^{\circ} \mathrm{C}$, in which the elements of $\mathrm{O}$ and $\mathrm{H}$ are largely removed due to the dehydration and condensation reactions ${ }^{36}$. The following gradual mass loss is due to the decomposition of the functional groups under the higher temperature, suggesting that the carbonization temperature control can tune the amount of the remained functional groups. We hence prepared the BC-derived 3D carbon current collectors by treating the freezing-dried $\mathrm{BC}$ in argon under different temperatures of 500,800 and $1500{ }^{\circ} \mathrm{C}$, and denoted the obtained carbon materials as BC-500, BC-800 and $\mathrm{BC}-1500$, respectively (Fig. S3). The as-obtained material is a flexible carbon scaffold composed of the interconnect nanofibers with a diameter of about 10-20 nm (Fig. 1b, c). As characterized by the SEM, the above samples carbonized at different temperatures show similar microscale morphologies (Fig. 1d-f). They all have a highly porous network structure composed of numerous ultrathin nanofibers. These characteristics enable the mechanical robustness and the fast electron transfer in the 3D carbon network.

The surface chemistry was characterized by the FTIR spectroscopy. As shown in Fig. 1g, for the pristine BC, the peaks of $\mathrm{O}-\mathrm{H}$ stretching vibration $\left(3330 \mathrm{~cm}^{-1}\right), \mathrm{C}-\mathrm{H}$ stretching vibration $\left(2900 \mathrm{~cm}^{-1}\right), \mathrm{O}-\mathrm{H}$ bending vibration of the absorbed water $\left(1630 \mathrm{~cm}^{-1}\right), \mathrm{C}-\mathrm{H}$ bending vibration (1430 $\mathrm{cm}^{-1}$ ) and $\mathrm{C}-\mathrm{O}-\mathrm{C}$ stretching vibration $\left(1000-1300 \mathrm{~cm}^{-1}\right)$ can be observed, suggesting the existence of many hydroxyl groups and ether bonds ${ }^{37-39}$. The pyrolysis at $500{ }^{\circ} \mathrm{C}$ mainly removed the $\mathrm{C}-\mathrm{O}-\mathrm{C}$ groups, but some of the hydroxyl groups and $\mathrm{C}-$ $\mathrm{H}$ bonds were remained. At $800{ }^{\circ} \mathrm{C}$, the peaks of hydroxyl groups and $\mathrm{C}-\mathrm{H}$ bonds can still be seen, but their intensity further decreased. After the pyrolysis at $1500{ }^{\circ} \mathrm{C}$, the peaks of the oxygen-containing groups and $\mathrm{C}-\mathrm{H}$ bonds disappeared. Higher carbonization temperature leads to better conductivity, and the four-point probe tests show the electric conductivities of $\mathrm{BC}-500, \mathrm{BC}-800$ and $\mathrm{BC}-1500$ are $0.0238,1.23$ and 15.5 

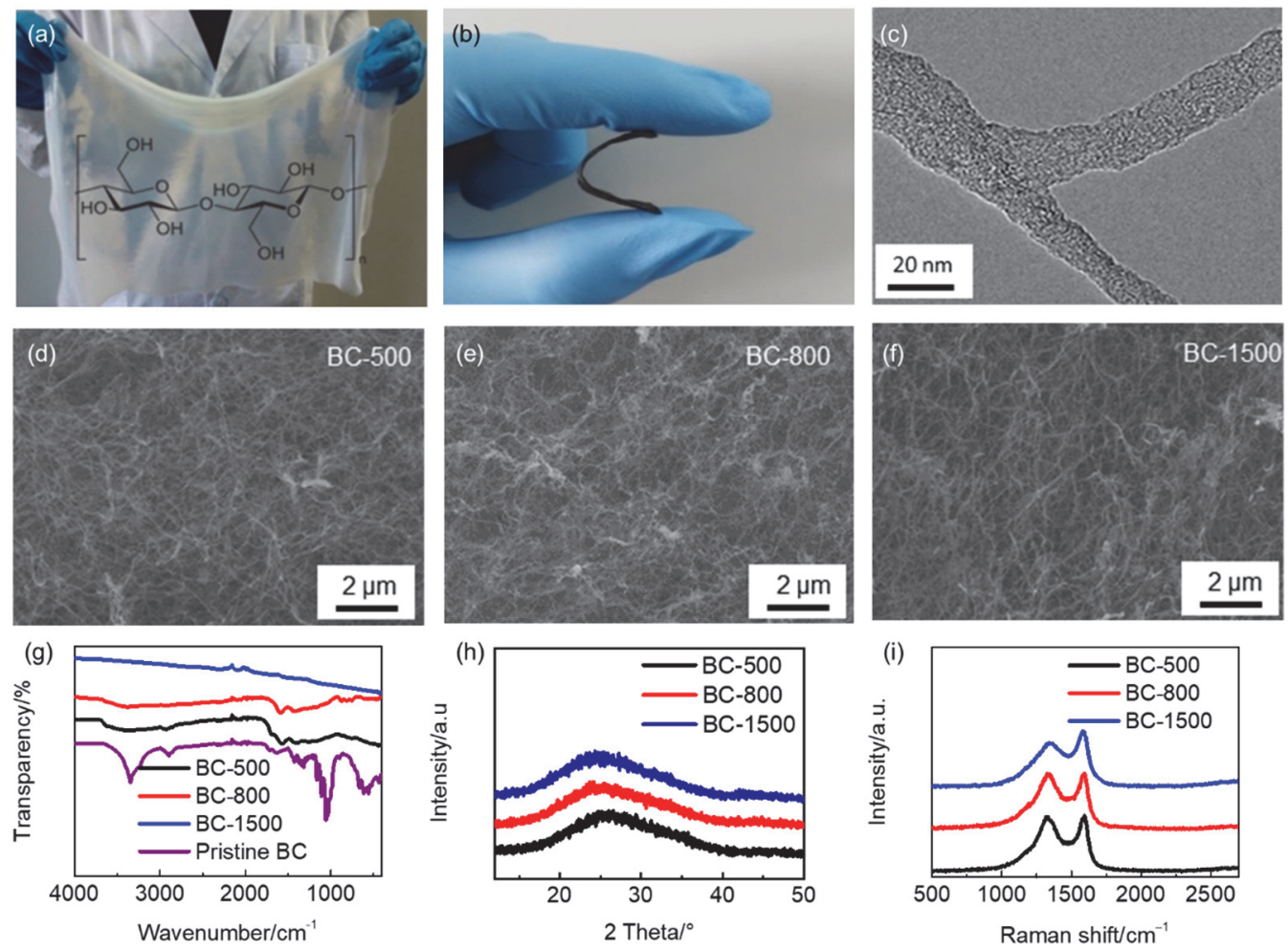

Fig. 1 Fabrication and structural characterization of the 3D interconnected carbon fibers from BC.

(a) A pristine BC pellicle, and (b) the flexible carbonized BC. (c) TEM image of the carbonized BC. SEM images of (d) BC-500, (e) BC-800 and (f) BC-1500.

(g) FTIR spectra, (h) XRD, (i) Raman spectra of BC-500, BC-800 and BC-1500.

$\mathrm{S} \cdot \mathrm{cm}^{-1}$, respectively. As shown in the XRD patterns (Fig. 1h), the broad (002) peaks at $26^{\circ}$ indicate their amorphous structure. In the Raman spectra, the ratios of $I_{\mathrm{D}} / I_{\mathrm{G}}$ of $\mathrm{BC}-500, \mathrm{BC}-800$ and BC-1500 are 0.98, 0.96 and 0.79, respectively (Fig. 1i). The lowest ratio of $I_{\mathrm{D}} / I_{\mathrm{G}}$ of BC-1500 suggests that it has the smallest concentration of defects. The $I_{\mathrm{D}} / I_{\mathrm{G}}$ ratios of $\mathrm{BC}-500$ and $\mathrm{BC}-$ 800 are similar, suggesting their concentrations of defects are close, which provides the abundant nucleation sites for $\mathrm{Li}^{+}$ion deposition ${ }^{40}$. However, the much lower conductivity of BC-500 may not be favorable to the electrochemical deposition of $\mathrm{Li}$.

To study the $\mathrm{Li}^{+}$ion deposition behaviors on the above three samples, coin cells were assembled with Li metal as the counter electrode. As shown in Fig. 2a-c, the nucleation overpotentials on BC-500, BC-800 and BC-1500 are 47,30 and $43 \mathrm{mV}$, respectively. The large nucleation overpotential of $\mathrm{BC}-500$ should be mainly ascribed to its low electric conductivity, which also leads to the high growth overpotential in the following plating process. But for the BC-1500, the lack of functional groups should be the main reason. The lowest nucleation overpotential of $\mathrm{BC}-800$ could be attributed to the synergic effects of the hydroxyl groups and its excellent electric conductivity to enable a smoother and more uniform $\mathrm{Li}^{+}$ion deposition. The morphologies of the samples after $1 \mathrm{mAh} \cdot \mathrm{cm}^{-2}$ $\mathrm{Li}$ plating were characterized by SEM. The top-view morphologies are shown in Fig. $2 \mathrm{~d}$ and $\mathrm{f}$, the non-uniform $\mathrm{Li}^{+}$ ion deposition is observed on the BC-500 and BC-1500 surfaces. In the cross-section images, Li deposits are observed on the top surfaces of BC-500 (Fig. 2g) and BC-1500 (Fig. 2i). In sharp contrast, the surface of BC-800 is quite smooth without dendrite formation (Fig. 2e). Li is uniformly deposited along the whole cross-section, and no Li deposits are observed on its top surface (Fig. 2h). In the magnified images (Fig. 2e insert and Fig. S4), the nanofibers of BC-800 after Li plating are obviously thicker than the control samples, suggesting the uniform dendrite-free deposition of $\mathrm{Li}^{+}$ions on the surface of the fibers. The advantage of the BC-derived 3D current collector is further demonstrated by the different morphologies with $2 \mathrm{mAh} \cdot \mathrm{cm}^{-2} \mathrm{Li}$ deposited on BC-800 and normally-used $\mathrm{Cu}$ foil. As shown in Fig. S5a, b, the pristine surface of $\mathrm{Cu}$ foil is smooth, and after the plating process, Li dendrites are observed on its surface (Fig. S5e). The cross-section image shows the thickness of the Li deposit is about $10 \mu \mathrm{m}$ (Fig. S5f). After the stripping process, some Li debris remained on the surface, forming the "dead Li" (Fig. S5i, j). In contrast, the surface morphologies of BC- 800 are very smooth and no Li dendrite is observed during the whole process (Fig. S5c, g, k). The thickness of the pristine BC-800 is about $20 \mu \mathrm{m}$ (Fig. S5d), and after the plating and stripping processes, very minor $(<5 \%)$ thickness changes are observed (Figs. S5h, 1).

The electrochemical performance of the samples was then evaluated based on coin-type half cells. The details of the cell assembling process and the test conditions can be found in the 

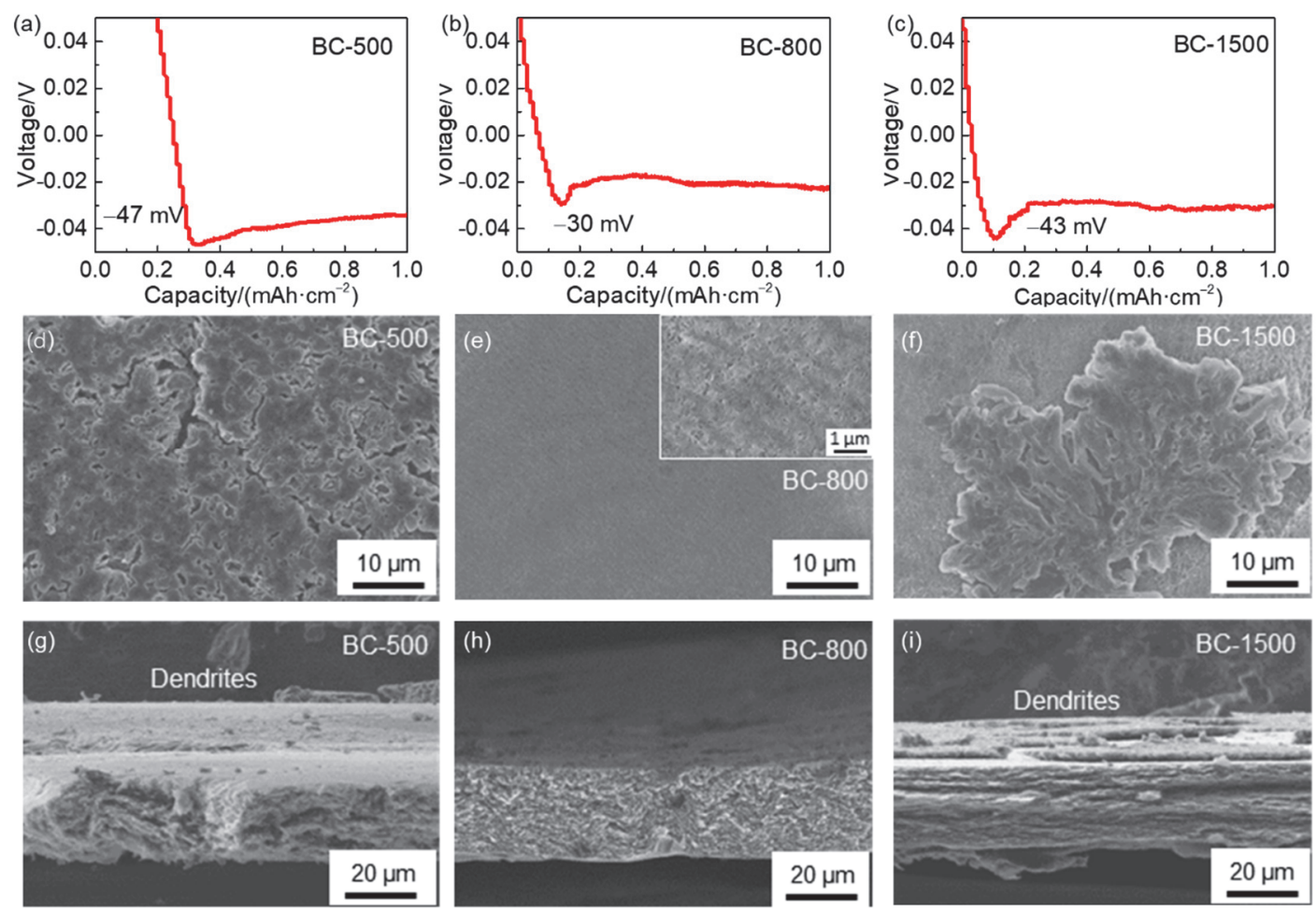

Fig. 2 The Li plating behaviors on the BC-derived 3D current collector.

The Li electrochemical plating curves of (a) BC-500, (b) BC-800, and (c) BC-1500. SEM images of the top-view and cross-section morphologies of (d, g) BC-500, (e, h) BC-800, and (g, i) BC-1500 after Li plating.

experiment section. The $\mathrm{CE}$ during cycling of the $\mathrm{BC}$-derived $3 \mathrm{D}$ current collector under a current density of $2 \mathrm{~mA} \cdot \mathrm{cm}^{-2}$ with a cycling capacity of $4 \mathrm{mAh} \cdot \mathrm{cm}^{-2}$ was recorded (Fig. 3a). The $\mathrm{CE}$ of BC-500 decays very quickly and the $\mathrm{CE}$ of BC-1500 also fluctuates in the initial cycles and then falls rapidly. For comparison, the $\mathrm{CE}$ of $\mathrm{BC}-800$ reaches $98 \%$ and remains stable for more than 150 cycles. When the current density increased to $3 \mathrm{~mA} \cdot \mathrm{cm}^{-2}$ with a cycling capacity of $1 \mathrm{mAh} \cdot \mathrm{cm}^{-2}$ (Fig. 3b), the $\mathrm{CE}$ of BC-500 still drops immediately at the initial stage of the cycling and the $\mathrm{CE}$ of $\mathrm{BC}-1500$ keeps stable in the initial cycles and then drops after about 40 cycles. In contrast, the $\mathrm{CE}$ of BC-800 shows a stable CE of $97 \%$ for nearly 150 cycles. These results show that $\mathrm{BC}$-derived $3 \mathrm{D}$ current collector has the comparable electrochemical performance to that of recentlyreported 3D current collectors (Table S1), and the most obvious advantage of such current collector is the low cost and the easy preparation method. EIS was used to further illustrate the differences of the electrochemical behaviors. As shown in Fig. $3 \mathrm{c}$ and $\mathrm{d}$, the semicircle represents the charge transfer resistance ( $R_{\mathrm{ct}}$. Before cycling, the $R_{\mathrm{ct}}$ of $\mathrm{BC}-500, \mathrm{BC}-800$ and $\mathrm{BC}-1500$ are 41.7, 20.2 and $15.9 \Omega$, respectively (Fig. 3c). The highest $R_{\text {ct }}$ of BC-500 is probably due to its low electric conductivity for its low carbonization temperature. The $R_{\mathrm{ct}}$ of $\mathrm{BC}-800$ is slightly larger than $\mathrm{BC}-1500$, which could be ascribed to that $\mathrm{BC}-1500$ has a higher electric conductivity than $\mathrm{BC}-800$. After the cycling, the $R_{\mathrm{ct}}$ of $\mathrm{BC}-500, \mathrm{BC}-800$ and $\mathrm{BC}-1500$ change to 13.8, 3.5 and $7.0 \Omega$ (Fig. 3d). The smallest $R_{\mathrm{ct}}$ of $\mathrm{BC}-800$ indicates it has little accumulation of broken SEI and "dead Li" on the surface of electrodes ${ }^{35}$. The microscale morphologies after the Li stripped were characterized by SEM. A large amount of "dead Li" is observed on BC-500 (Fig. 3e) and BC1500 (Fig. 3g) surfaces and the surface of BC-1500 is much coarser with larger "dead Li" (Fig. 3h, j). In contrast, the surface of BC-800 is quite smooth (Fig. 3f) and in the zoomed images, the nanofiber morphologies can be clearly observed (Fig. 3i) which means the uniformly deposited Li on the nanofibers can be fully stripped. XPS was further used to reveal the surface chemistry of the samples after the cycling test with Li stripped. In the high-resolution $\mathrm{O} 1 \mathrm{~s}$ spectra (Fig. S6a), the peaks at 528.0, 529.5, 530.6, 531.6 and $533.0 \mathrm{eV}$ are related to $\mathrm{Li}_{2} \mathrm{O}$, $\mathrm{ROLi}, \mathrm{C}_{6} \mathrm{H}_{5} \mathrm{O}, \mathrm{C}=\mathrm{O}$ and $\mathrm{C}-\mathrm{O}$, respectively ${ }^{41,42}$. The highresolution Li $1 s$ spectra (Fig. S6b) contain four peaks at 52.7 (Li), $53.7\left(\mathrm{Li}_{2} \mathrm{O}\right), 54.2\left(\mathrm{ROCO}_{2} \mathrm{Li}\right)$ and $55.4 \mathrm{eV}\left(\mathrm{Li}_{2} \mathrm{CO}_{3} / \mathrm{LiOH}\right)^{43}$. Compared with BC-500 and BC-1500, much higher content of $\mathrm{Li}_{2} \mathrm{CO}_{3}$ can be found in both $\mathrm{O} 1 s$ and Li $1 s$ spectra of BC-800, the component was reported to show high ion transport ability ${ }^{2,44}$, which enables a faster $\mathrm{Li}^{+}$ion diffusion across the SEI on $\mathrm{BC}-800$ and decreases the $\mathrm{Li}^{+}$ion concentration polarization on the interface, leading to a more uniform $\mathrm{Li}$ plating. In addition, the high intensities of Li signal in $\mathrm{Li} 1 s$ spectra are shown on BC-500 and BC-1500 after Li stripping, indicating the accumulation of massive "dead $\mathrm{Li}$ " on the surface, which is consistent with the surface morphologies discussed above. The high intensities of the peaks of $\mathrm{Li}_{2} \mathrm{O}$ 

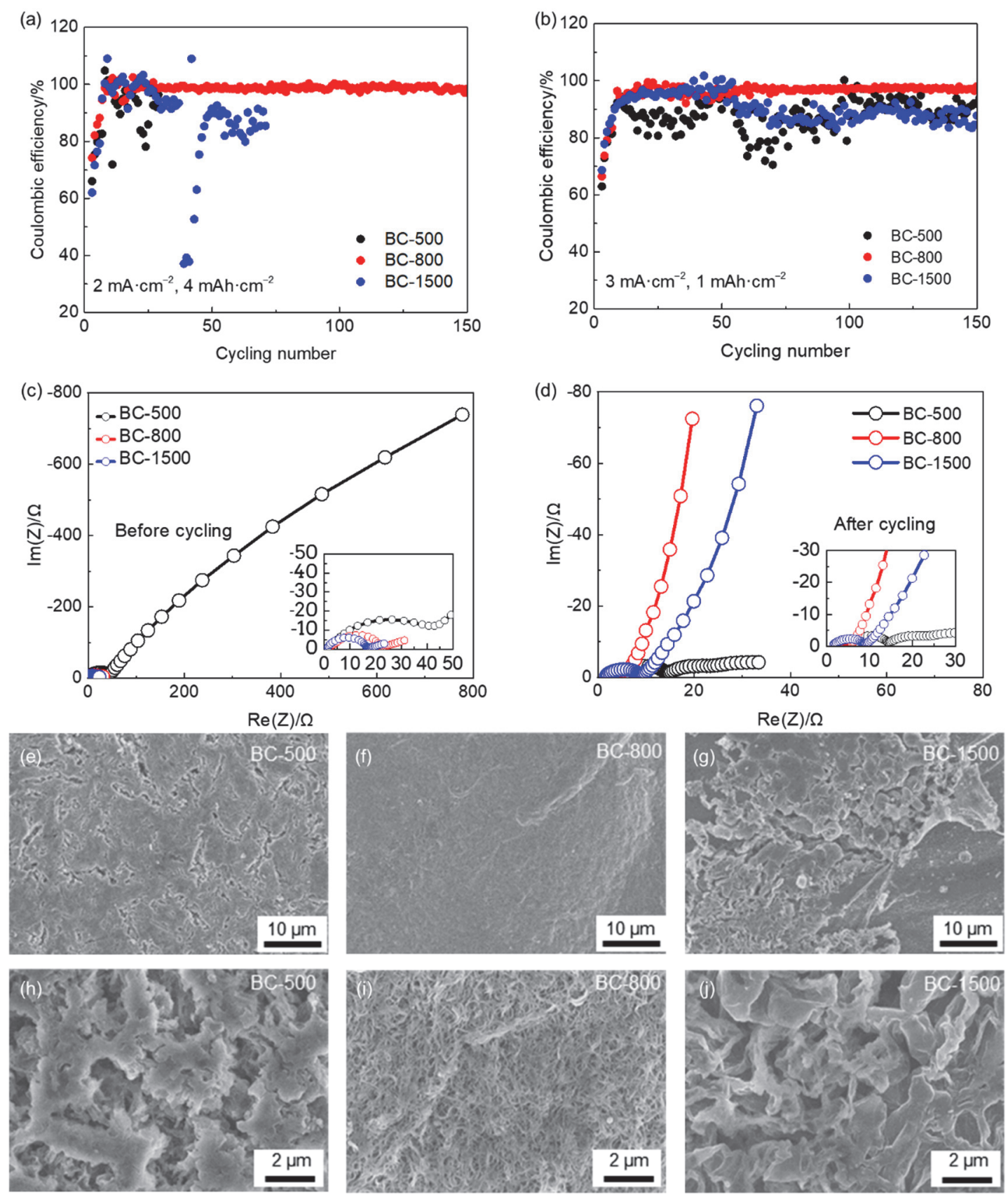

Fig. 3 Electrochemical performance of the BC-derived current collectors.

The CEs in the cycling (a) at a current density of $2 \mathrm{~mA} \cdot \mathrm{cm}^{-2}$ with a capacity of $4 \mathrm{mAh} \cdot \mathrm{cm}^{-2}$ and (b) at a current density of $3 \mathrm{~mA} \cdot \mathrm{cm}^{-2}$ with a capacity of $1 \mathrm{mAh} \cdot \mathrm{cm}^{-2}$

EIS profiles of the three BC-derived current collectors (c) before and (d) after a cycling test. SEM images of the surface morphologies of (e, h) BC-500,

(f, i) BC-800, and (g, j) BC-1500 after the cycling test.

$(528.0 \mathrm{eV})$ in $\mathrm{O} 1 s$ spectra of $\mathrm{BC}-500$ and $\mathrm{BC}-1500$ further suggest the severe irreversible reactions induced by "dead $\mathrm{Li}$ ". The inert "dead Li" hinders the normal Li plating/stripping processes, and results in the inferior performance of the samples.

To further demonstrate the advantages of BC-derive 3D current collectors, we compared the electrochemical performance of BC-800 with $\mathrm{Cu}$ foil. As shown in Fig. S7a, the $\mathrm{CE}$ of $\mathrm{Cu}$ foil oscillates around $95 \%$ and then drops to about $80 \%$ in 160 cycles under the current density of $1 \mathrm{~mA} \cdot \mathrm{cm}^{-2}$ with a cycling capacity of $0.5 \mathrm{mAh} \cdot \mathrm{cm}^{-2}$, whereas the CE of BC-800 keeps stable around $98 \%$ for more than 200 cycles. When increasing the current density to $3 \mathrm{~mA} \cdot \mathrm{cm}^{-2}$, the CE of BC-800 also maintains stable for nearly 150 cycles, but the $\mathrm{CE}$ of $\mathrm{Cu}$ foil drops after 90 cycles (Fig. S7b). Moreover, with the current density of $2 \mathrm{~mA} \cdot \mathrm{cm}^{-2}$ and a higher capacity of $4 \mathrm{mAh} \cdot \mathrm{cm}^{-2}$, the $\mathrm{CE}$ of $\mathrm{Cu}$ foil decays below $80 \%$ in 70 cycles, while the $\mathrm{CE}$ of BC-800 keeps stable at $97 \%$ for nearly 150 cycles (Fig. S7c). Actually, the uniformly distributed functional groups on the surface of the 3D fiber network guarantee uniform nucleation 
and the followed dendrite-free $\mathrm{Li}^{+}$ion deposition. This result also demonstrates that the sufficient void space in this BCderived 3D current collector accommodates the volume expansion of Li metal, enabling the stable cycling performance under a high cycling capacity. After the cycling test, the surface morphologies of the two kinds of electrodes were characterized by SEM. The surface of BC- 800 is very smooth and the fiber shape of the fibers was observed (Fig. S8a, c). For comparison, $\mathrm{Li}$ dendrites cover on the whole surface of $\mathrm{Cu}$ foil (Fig. S8b, d).

To demonstrate the potential of the $3 \mathrm{D}$ current collector for the real use, we firstly plated $3 \mathrm{mAh} \cdot \mathrm{cm}^{-2} \mathrm{Li}$ into $\mathrm{BC}-800$ (denoted as $3 \mathrm{D} \mathrm{Li-BC)}$, in which the mass ratio of the carbon current collector is only about $28.8 \%$. Its performance in symmetrical cells is shown in Fig. 4a, and the overpotentials of the discharging/charging processes of the 3D Li-BC keep stable at about $16 \mathrm{mV}$ for more than $600 \mathrm{~h}$ at the current density of 1 $\mathrm{mA} \cdot \mathrm{cm}^{-2}$ with the capacity of $1 \mathrm{mAh} \cdot \mathrm{cm}^{-2}$. In contrast, the overpotentials of Li metal electrodes are about $20 \mathrm{mV}$, and the short circuit happens in less than $300 \mathrm{~h}$. When increasing the current density to $2 \mathrm{~mA} \cdot \mathrm{cm}^{-2}$, the overpotentials of $3 \mathrm{D} \mathrm{Li}-\mathrm{BC}$ remain stable at about $26 \mathrm{mV}$ for more than $300 \mathrm{~h}$, while the overpotentials of Li metal electrodes increase sharply after 150 h (Fig. 4b). To evaluate the relationship between the depths of discharge (DOD) and electrochemical performance of the 3D current collectors, the $3 \mathrm{D} \mathrm{Li}-\mathrm{BC}$ anodes with the 2, 1.33, and 1
$\mathrm{mAh} \cdot \mathrm{cm}^{-2} \mathrm{Li}$ were prepared and characterized in the symmetric cell tests. The testing current densities and capacities are 1 $\mathrm{mA} \cdot \mathrm{cm}^{-2}$ and $1 \mathrm{mAh} \cdot \mathrm{cm}^{-2}$, respectively, and thus, the DOD for the above three samples are $50 \%, 75 \%$ and $100 \%$, respectively. The results in Fig. S9 suggest the cells can work well at the DOD of $50 \%$ and $75 \%$. However, with the higher DOD of $100 \%$, the voltage of the cell decreases sharply when the capacity reaches $0.9 \mathrm{mAh}$, corresponding to about $79.6 \%$ of the pre-deposited Li. The depletion of Li may be due to the consumption of $\mathrm{Li}^{+}$ion by forming SEI.

To evaluate the performance of $3 \mathrm{D} \mathrm{Li}-\mathrm{BC}$ anode in a full cell, the $3 \mathrm{D} \mathrm{Li}-\mathrm{BC}$ was paired with the cathode material of NCA to assemble a Li-NCA cell. As shown in Fig. 4c, the capacity of the cell with $3 \mathrm{D} \mathrm{Li-BC}$ declines very slowly to $102 \mathrm{mAh} \cdot \mathrm{g}^{-1}$ after 150 cycles, while the capacity of the cell with Li metal electrode plummets below $40 \mathrm{mAh} \cdot \mathrm{g}^{-1}$ only after 75 cycles. The charging/discharging curves of the two cells are shown in Fig. $4 \mathrm{~d}$. At the initial cycle, the electrochemical curves of the two cells are similar. After 50 cycles, the overpotential of the cell with 3D Li-BC anode is obviously smaller. This superior electrochemical performance of the $3 \mathrm{D}$ Li-BC cell mainly results from the $3 \mathrm{D}$ interconnected porous network with sufficient, homogeneous oxygen-containing groups, which induces uniform $\mathrm{Li}$ nucleation and suppresses the dendrite growth.
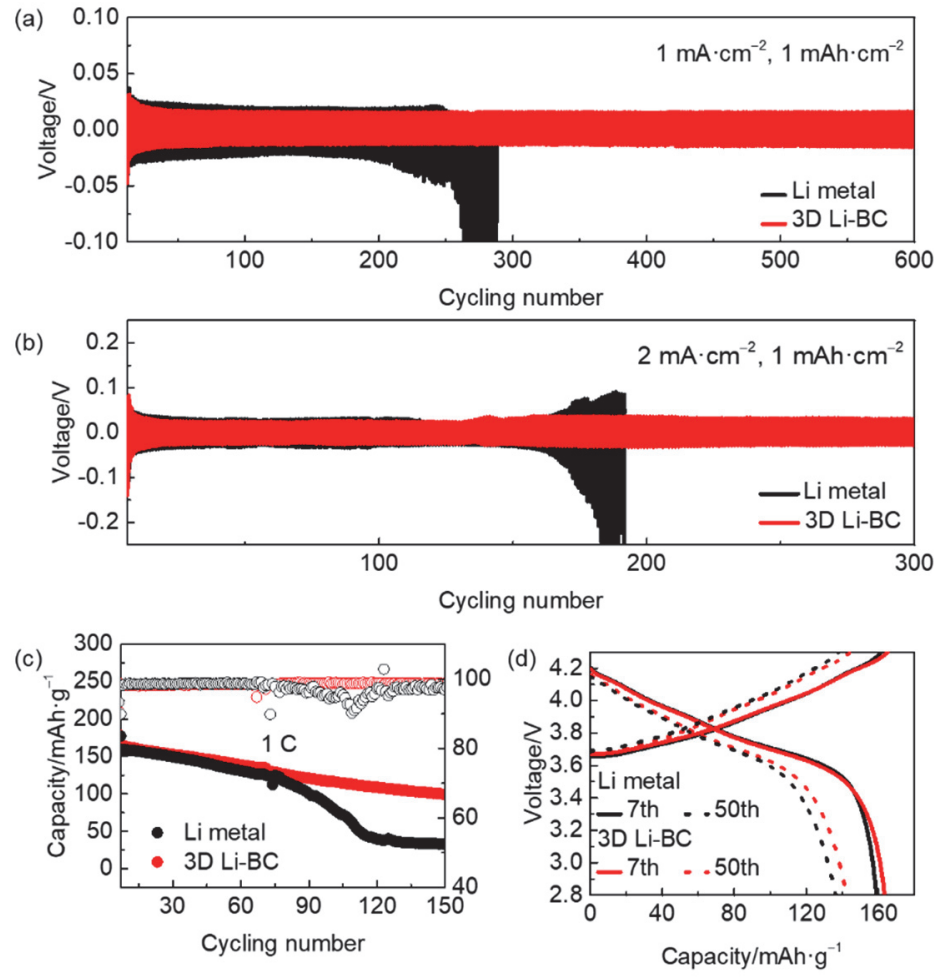

Fig. 4 Electrochemical performance of a 3D Li-BC-based full cell. 
The above performance demonstrates the potential use of BC-derived 3D current collector in the $\mathrm{Li}$ metal anode. However, its large surface area leads to the large irreversible capacity and low CE due to the side reactions in the cycling. In addition, the void space in the 3D current collector will absorb a large number of electrolytes in batteries, lowering the energy density based on the whole device. These issues require to be considered further for the practical applications.

\section{Conclusions}

A 3D carbon current collector was prepared by the direct carbonization of bacterial cellulose, which enables dendritefree deposition for the Li metal anode. The 3D porous network composed of connected nanofibers, serving as a mechanically robust and highly conductive scaffold, effectively suppresses the dendrite growth by decreasing current density and increasing the uniform nucleation sites with the oxygencontaining functional groups. In addition, the 3D structure also accommodates volume expansion. As a result, the batteries with the $3 \mathrm{D}$ current collector work stably at a current density of 3 $\mathrm{mA} \cdot \mathrm{cm}^{-2}$ and also have a stable 150 cycle life under a high capacity of $4 \mathrm{mAh} \cdot \mathrm{cm}^{-2}$. The Li-containing 3D current collector with $71.2 \%$ Li metal also demonstrates good electrochemical performance in symmetric cells and Li-NCA cells, further suggesting its potential for practical uses. Last but not least, the low cost of bacterial cellulose and the simple preparation process also endow the $3 \mathrm{D}$ current collector with obvious advantages for large-scale productions.

Supporting Information: available free of charge via the internet at http://www.whxb.pku.edu.cn.

\section{References}

(1) Lin, D.; Liu, Y.; Cui, Y. Nat. Nanotechnol. 2017, 12, 194. doi: 10.1038/nnano.2017.16

(2) Cheng, X. B.; Zhang, R.; Zhao, C. Z.; Zhang, Q. Chem. Rev. 2017, 117, 10403. doi: 10.1021/acs.chemrev.7b00115

(3) Tikekar, M. D.; Choudhury, S.; Tu, Z.; Archer, L. A. Nat. Energy 2016, 1, 1. doi: 10.1038/nenergy.2016.114

(4) Yue, X. Y; Cui, M.; Bao, J.; Yang, S. Y.; Chen, D.; Wu, X. J.; Zhou, Y. N. Acta Phys. -Chim. Sin. 2021, 37, 2005012. [岳昕阳, 马萃, 包 哑, 杨思宇, 陈东, 吴晓京, 周永宁. 物理化学学报, 2021, 37, 2005012.] doi: 10.3866/PKU.WHXB202005012

(5) Qian, J.; Xu, W.; Bhattacharya, P.; Engelhard, M.; Henderson, W. A.; Zhang, Y.; Zhang, J. G. Nano Energy 2015, 15, 135. doi: 10.1016/j.nanoen.2015.04.009

(6) Lu, Y.; Tu, Z.; Archer, L. A. Nat. Mater. 2014, 13, 961. doi: $10.1038 /$ nmat 4041

(7) Zheng, J.; Engelhard, M. H.; Mei, D.; Jiao, S.; Polzin, B. J.; Zhang, J. G.; Xu, W. Nat. Energy 2017, 2, 17012. doi: $10.1038 /$ nenergy.2017.12

(8) Zhang, X. Q.; Chen, X.; Cheng, X. B.; Li, B. Q.; Shen, X.; Yan, C.; Huang, J. Q.; Zhang, Q. Angew. Chem. Int. Ed. 2018, 57, 5301. doi: 10.1002/anie.201801513

(9) Zhang, X. Q.; Chen, X.; Xu, R.; Cheng, X. B.; Peng, H. J.; Zhang, R.; Huang, J. Q.; Zhang, Q. Angew. Chem. Int. Ed. 2017, 56, 14207. doi: 10.1002/anie. 201707093

(10) Li, W.; Yao, H.; Yan, K.; Zheng, G.; Liang, Z.; Chiang, Y. M.; Cui, Y. Nat. Commun. 2015, 6, 7436. doi: 10.1038/ncomms 8436

(11) Yang, S. J.; Xu, X. Q., Cheng, X. B.; Wang, X. M.; Chen, J. X.; Xiao, Y.; Yuan, H.; Liu, H.; Chen, A. B.; Zhu, W. C.; et al. Acta Phys. -Chim. Sin. 2021, 37, 2007058. [杨世杰, 徐向群, 程新兵, 王金萌, 陈金秀, 肖也, 袁洪, 刘鹤, 陈爱兵, 朱万诚, 等. 物理 化学学报, 2021, 37, 2007058.] doi: 10.3866/PKU.WHXB202007058

(12) Qian, J.; Henderson, W. A.; Xu, W.; Bhattacharya, P.; Engelhard, M.; Borodin, O.; Zhang, J. G. Nat. Commun. 2015, 6, 6362. doi: $10.1038 /$ ncomms 7362

(13) Liu, B.; Xu, W.; Yan, P.; Kim, S. T.; Engelhard, M. H.; Sun, X.; Mei, D.; Cho, J.; Wang, C. M.; Zhang, J. G. Adv. Energy Mater. 2017, 7, 1602605. doi: 10.1002/aenm.201602605

(14) Wu, C.; Zhou, Y.; Zhu, X. L.; Zhan, M. Z.; Yang, H. X.; Qian, J. F. Acta Phys. -Chim. Sin. 2021, 37, 2008044. [吴晨, 周颖, 朱晓龙, 詹莣之, 杨汉西, 钱江锋. 物理化学学报, 2021, 37, 2008044.] doi: 10.3866/PKU.WHXB202008044

(15) Li, Y.; Sun, Y.; Pei, A.; Chen, K.; Vailionis, A.; Li, Y.; Zheng, G.; Sun, J.; Cui, Y. ACS Central Sci. 2018, 4, 97. doi: 10.1021/acscentsci.7b00480

(16) Bucur, C. B.; Lita, A.; Osada, N.; Muldoon, J. Energy Environ. Sci. 2016, 9 , 112. doi: $10.1039 / \mathrm{c} 5 \mathrm{ee} 03056 \mathrm{k}$

(17) Liu, K.; Pei, A.; Lee, H. R.; Kong, B.; Liu, N.; Lin, D.; Liu, Y.; Liu, C.; Hsu, P. C.; Bao, Z.; Cui, Y. J. Am. Chem. Soc. 2017, 139, 4815. doi: $10.1021 /$ jacs.6b13314

(18) Zheng, G.; Lee, S. W.; Liang, Z.; Lee, H. W.; Yan, K.; Yao, H.; Wang, H.; Li, W.; Chu, S.; Cui, Y. Nat. Nanotechnol. 2014, 9, 618. doi: $10.1038 /$ nnano.2014.152

(19) Liang, X.; Pang, Q.; Kochetkov, I. R.; Sempere, M. S.; Huang, H.; Sun, X.; Nazar, L. F. Nat. Energy 2017, 2, 17119. doi: 10.1038/nenergy.2017.119

(20) Wei, Z.; Ren, Y.; Sokolowski, J.; Zhu, X.; Wu, G. InfoMat 2020, 2 , 483. doi: $10.1002 /$ inf2.12097

(21) Yao, Y. X.; Zhang, X. Q.; Li, B. Q.; Yan, C.; Chen, P. Y.; Huang, J. Q.; Zhang, Q. InfoMat 2020, 2, 379. doi: 10.1002/inf2.12046

(22) Han, X.; Gong, Y.; Fu, K.; He, X.; Hitz, G. T.; Dai, J.; Pearse, A.; Liu, B.; Wang, H.; Rubloff, G.; et al. Nat. Mater. 2016, 16, 572. doi: $10.1038 /$ nmat 4821

(23) Fu, K.; Gong, Y.; Dai, J.; Gong, A.; Han, X.; Yao, Y.; Wang, C.; 
Wang, Y.; Chen, Y.; Yan, C.; et al. Proc. Natl. Acad. Sci. U. S. A. 2016, 113, 7094. doi: 10.1073/pnas.1600422113

(24) Luo, W.; Gong, Y.; Zhu, Y.; Li, Y.; Yao, Y.; Zhang, Y.; Fu, K.; Pastel, G.; Lin, C. F.; Mo, Y.; et al. Adv. Mater. 2017, 29, 1606042. doi: 10.1002/adma.201606042

(25) Liu, Y.; Zheng, L.; Gu, W.; Shen, Y. B.; Chen, L. W. Acta Phys. -Chim. Sin. 2021, 37, 2004058. [刘亚, 郑否, 谷巍, 沈炎宾, 陈立桅. 物理化学学报, 2021, 37, 2004058.] doi: 10.3866/PKU.WHXB202004058

(26) Zhang, R.; Cheng, X. B.; Zhao, C. Z.; Peng, H. J.; Shi, J. L.; Huang, J. Q.; Wang, J. F.; Wei, F.; Zhang, Q. Adv. Mater. 2016, 28, 2155. doi: 10.1002/adma.201504117

(27) Liu, Y.; Lin, D.; Liang, Z.; Zhao, J.; Yan, K.; Cui, Y. Nat. Commun. 2016, 7, 10992. doi: 10.1038/ncomms 10992

(28) Yang, C. P.; Yin, Y. X.; Zhang, S. F.; Li, N. W.; Guo, Y. G. Nat. Commun. 2015, 6, 8058. doi: 10.1038/ncomms9058

(29) Lin, D.; Liu, Y.; Liang, Z.; Lee, H. W.; Sun, J.; Wang, H.; Yan, K.; Xie, J.; Cui, Y. Nat. Nanotechnol. 2016, 11, 626. doi: $10.1038 /$ nnano.2016.32

(30) Yun, Q.; He, Y. B.; Lv, W.; Zhao, Y.; Li, B.; Kang, F.; Yang, Q. H. Adv. Mater. 2016, 28, 6932. doi: 10.1002/adma.201601409

(31) Liang, Z.; Lin, D.; Zhao, J.; Lu, Z.; Liu, Y.; Liu, C.; Lu, Y.; Wang, H.; Yan, K.; Tao, X.; Cui, Y. Proc. Natl. Acad. Sci. U. S. A. 2016, 113, 2862. doi: 10.1073/pnas. 1518188113

(32) Wang, Q.; Wu, K.; Wang, H. C.; Liu, W.; Zhou, H. H. Acta Phys. -Chim. Sin. 2021, 37, 2007092. [王寒, 吴恺, 王航超, 刘文, 周恒辉. 物理化学学报, 2021, 37, 2007092.] doi: 10.3866/PKU.WHXB202007092

(33) Chazalviel, J. N. Phys. Rev. A 1990, 42, 7355. doi: 10.1103/PhysRevA.42.7355

(34) Cheng, X. B.; Hou, T. Z.; Zhang, R.; Peng, H. J.; Zhao, C. Z.; Huang, J. Q.; Zhang, Q. Adv. Mater. 2016, 28, 2888. doi: 10.1002/adma.201506124

(35) Jin, C.; Sheng, O.; Luo, J.; Yuan, H.; Fang, C.; Zhang, W.; Huang, H.; Gan, Y.; Xia, Y.; Liang, C.; Zhang, J.; Tao, X. Nano Energy 2017, 37, 177. doi: 10.1016/j.nanoen.2017.05.015

(36) Lin, Y. C.; Cho, J.; Tompsett, G. A.; Westmoreland, P. R.; Huber, G. W. J. Phys. Chem. C 2009, 113, 20097. doi: 10.1021/jp906702p

(37) Lee, H. J.; Chung, T. J.; Kwon, H. J.; Kim, H. J.; Tze, W. T. Y. Cellulose 2012, 19, 1251. doi: 10.1007/s10570-012-9705-5

(38) Feng, Y.; Zhang, X.; Shen, Y.; Yoshino, K.; Feng, W. Carbohydr. Polym. 2012, 87, 644. doi: 10.1016/j.carbpol.2011.08.039

(39) Mueller, D.; Mandelli, J. S.; Marins, J. A.; Soares, B. G.; Porto, L. M.; Rambo, C. R.; Barra, G. M. O. Cellulose 2012, 19, 1645. doi: 10.1007/s10570-012-9754-9

(40) Mukherjee, R.; Thomas, A. V.; Datta, D.; Singh, E.; Li, J.; Eksik, O.; Shenoy, V. B.; Koratkar, N. Nat. Commun. 2014, 5, 3710. doi: $10.1038 /$ ncomms 4710

(41) Gong, Y.; Zhang, M.; Cao, G. RSC Adv. 2015, 5, 26521. doi: 10.1039/C5RA01518A

(42) Zhang, J.; Wang, D. W.; Lv, W.; Zhang, S.; Liang, Q.; Zheng, D.; Kang, F.; Yang, Q. H. Energy Environ. Sci. 2017, 10, 370. doi: $10.1039 / \mathrm{c} 6 \mathrm{ee} 03367 \mathrm{a}$

(43) Wang, L.; Liu, J.; Yuan, S.; Wang, Y.; Xia, Y. Energy Environ. Sci. 2016, 9, 224. doi: 10.1039/C5EE02837J

(44) Guan, P.; Liu, L.; Lin, X. J. Electrochem. Soc. 2015, 162, A1798. doi: $10.1149 / 2.0521509$ jes 